\title{
Microbially enhanced heavy oil recovery through biodegradation using fungal extracellular enzymes from Aspergillus spp.
}

Junhui Zhang

Xinjiang University

\section{Hui Gao}

Northwest Agriculture and Forestry University

Hangxian Lai

Northwest Agriculture and Forestry University

Shibin $\mathrm{Hu}$

Northwest Agriculture and Forestry University

Quanhong Xue ( $\square$ xuequanhong6070@163.com)

Northwest Agriculture and Forestry University https://orcid.org/0000-0002-6886-9234

\section{Research}

Keywords: Heavy oil recovery, fungal enzyme preparation, enzymatic degradation, oil viscosity, biogas production

Posted Date: December 30th, 2019

DOI: https://doi.org/10.21203/rs.2.19561/v1

License: (9) (1) This work is licensed under a Creative Commons Attribution 4.0 International License. Read Full License 


\section{Abstract}

Background: The progressive depletion of light crude oils has led to increased focus on efficient exploitation of heavy oil reserves to meet energy demand. Microbial enhanced oil recovery make a significant contribution to the recovery of heavy oils; however, most use bacteria, with less attention paid to the potential of fungi. Therefore, this study proposes the use of fungi in the form of extracellular enzymes to degrade heavy oil and improve its physicochemical property, thus increasing fluidity of heavy oil.

Results: In this study, we investigated the efficiency of fungal extracellular enzymes in biotransformation and biodegradation of heavy oil fractions into light aliphatic and aromatic compounds and the feasibility of the use of such enzyme preparations in enhanced oil recovery. Two strains of Aspergillus spp., isolated from bitumen samples, showed good growth on plates of mineral salts medium with heavy oil as the sole carbon source. The fungal extracellular enzymes, with dehydrogenase and catechol 2,3-dioxygenase activities, exhibited the ability to degrade heavy oil, and coupled with abundant gas production. Gas chromatography analysis revealed a significant redistribution of $\mathrm{n}$ alkanes in the heavy oil caused by the action of the fungal enzymes, resulting in an increase in individual $\mathrm{n}$-alkanes. The viscosity of the heavy oil was decreased $66.33 \%$ by fungal enzymatic degradation.

Conclusions: These results demonstrate the potential of extracellular enzymes from Aspergillus spp. for applications in enhanced heavy oil recovery, including biotransformation of heavy to lighter crude oil and byproduct biogas formation.

\section{Background}

Crude oil is an important and non-renewable resource mineral resource to support economic and social development; it is the lifeblood of industry and the key source of energy. It is estimated that in the next 20 years, about $80-90 \%$ of global energy requirements will come from fossil fuels [1]. With the continuous depletion of light crude oil, and increasing global energy demand, the use of heavy oil resources is interesting for the economics of petroleum development. According to some estimates from the International Energy Agency, heavy oil represents at least half of the recoverable oil resources of the world [2]. Heavy crude oil is highly-viscous and closely related to natural bitumen. It has density $<20^{\circ} \mathrm{API}$ gravity (American Petroleum Institute) and viscosity $>200 \mathrm{mPa} \cdot \mathrm{s}$ in reservoir conditions [3]. The production, transportation, and refining of heavy oil presents operational difficulties and is costly compared to light crude oil because of the high viscosity and complex oil composition. Conventional heavy oil recovery technologies, such as thermal extraction techniques including steam flooding and in situ combustion, and cold production methods including alkaline drive, polymer injection, and miscible displacement processes, face great challenges in terms of complex operation and environmental costs [3,4]. Therefore, significant and less costly recovery techniques are required for exploration and production of heavy oil.

Microbial enhanced oil recovery (MEOR) has been successfully applied in crude oil recovery $[5,6]$. It is a cost-effective and environmentallyfriendly approach to increase heavy oil recovery compared to other conventional petroleum extraction technologies and has great potential and broad prospects [7]. MEOR is a biologically-based technology that uses microorganisms or their metabolites to increase recovery of residual oil; it was first proposed in the 1920s and was developed in the early 1980s [8, 9]. The main mechanisms of MEOR are [10]: (1) degradation of high-molecular-weight hydrocarbons to improve the liquidity of residual oil; (2) production of chemicals, such as biosurfactants, acids, solvents, and biopolymers that increase the oil sweep efficiency through altering oil/water/rock interfacial properties; and (3) generation of gases $\left(\mathrm{CO}_{2}, \mathrm{~N}_{2}, \mathrm{H}_{2}\right.$, and $\left.\mathrm{CH}_{4}\right)$ that can dissolve in crude oil to reduce the oil viscosity and increase the reservoir pressure. MEOR technology has been actively pursued both in laboratory and field conditions. In 2010, various countries allocated one-third of their oil recovery programs to MEOR, and up to $50 \%$ of trapped oil can be extracted after the primary and secondary phases of production using this tertiary recovery technology [6].

The MEOR method involving biodegradation or biotransformation of crude oil is a biocatalytic process involving conversion of heavier hydrocarbons to lighter ones by various types of enzymes, such as oxygenases, hydroxylases, dehydrogenases, and cytochrome P450 monooxygenases and dioxygenases [11]. Due to their versatility, bacteria play a major role in biodegradation of petroleum hydrocarbons. However, fungi have been shown to have stronger hydrocarbon-metabolizing abilities than bacteria [12]. Fungal extracellular enzymes, e.g., oxidases and hydrolases, may degrade long-chain petroleum hydrocarbons and complex polycyclic aromatic hydrocarbons [13, 14]. Recent laboratory studies have shown that fungal extracellular enzymes can be used to degrade paraffin, aromatic, and resin fractions of crude oil; the enzymatic degradation is associated with dynamic production of gases and organic acids, thereby reducing oil viscosity $[15,16]$. The use of enzymes to enhance oil recovery is one of the novel methods under consideration in recent research [17]. Nemati and Voordouw [18] have suggested that enzymes can be used to modify reservoir rock permeability by aiding in plugging using the products generated in catalyzed reactions. In China's Shengli oilfield, an enzyme-based reservoir blockage removing agent composed of proteinases and bacteria recovered dramatically the permeability of cores polluted by sandy crude oil and extended the validity of the production wells; this agent was applicable to releasing formation damage, removing wax, acidizing fluid, controlling sand, and water shutoff [19]. Enzymes have several

Page 2/20 
advantages over whole-cell catalysts, such as robustness, ease of modulation, and multiple usage strategies. Thus, enzymatic cracking is probably the most interesting target of biotechnology for enhanced heavy oil recovery [20].

In this study, we chose fungal extracellular enzymes from Aspergillus spp. as agents to degrade heavy oil. The aim of this study was to investigate the capacity of the fungal extracellular enzymes for heavy oil degradation; to determine the effects of enzymatic degradation on oil physic-chemical properties; and to demonstrate the potential of fungal enzymes for biodegradation and biotransformation of heavy crude oil in MEOR.

\section{Results And Discussion}

\section{Screening and identification of oil-degrading fungal strains}

Four pure fungal strains with the ability to degrade heavy oil, designated $\mathrm{HJ} 1$ to $\mathrm{HJ} 4$, were isolated from bitumen enrichment cultures. Two strains, $\mathrm{HJ} 2$ and HJ4, exhibited strong growth on oil plates of mineral salts medium (Fig. 1), and were selected as potential candidates for analysis of heavy oil biodegradation, extracellular enzyme production, and enzymatic degradation of heavy oil. Based on morphological analyses (Fig. 2) and partial sequencing of the rDNA-ITS genes (Fig. 3), strains HJ2 and HJ4 were identified as Aspergillus terreus and A. nidulans, respectively. The rDNA-ITS gene sequences of the two strains were deposited in the GenBank database with accession numbers MG 732935 and MG 732936. Several fungi of the genus Aspergillus isolated from petroleum-contaminated terrestrial environments are known to be able to degrade petroleum hydrocarbons. They can use petroleum hydrocarbons as their sole carbon and energy source and break them down to simpler compounds such as $\mathrm{CO}_{2}$ and $\mathrm{H}_{2} \mathrm{O}$ [21].

\section{Fungal degradation of heavy oil}

The ability of strains HJ2 and HJ4 to degrade heavy oil was initially tested by the growth of cultures on oil and bitumen plates of mineral salts medium (containing $20 \mathrm{~g} \mathrm{~L}-1$ heavy oil or bitumen), respectively (Fig. 1). The biodegradation of heavy oil was verified by observation of a decrease in the total weight of the heavy oil and a redistribution of its fractions (saturates, aromatics, resins, and asphaltenes). Table 1 showed that there was a significant difference $(P<0.05)$ between the control group and the treated samples in the total petroleum hydrocarbons. The degradation ratios of total petroleum hydrocarbons ( $15 \mathrm{~d}$ ) for the fungi HJ2 and HJ4 were $25.29 \%$ and $27.36 \%$, respectively. After $15 \mathrm{~d}$ of aerobic degradation saturates and asphaltenes were decreased by $36.19-39.08 \%$ and $7.92-10.89 \%$, respectively, while the aromatics and resins were increased by $2.70-5.02 \%$ and $16.00-18.00 \%$, respectively (Table 1). GC analysis provided a more detailed assessment of the heavy oil degradation and characterized the variation of saturates before and after fungal degradation. Both strains $\mathrm{HJ} 2$ and HJ4 were able to degrade the heavy oil efficiently; $33.33-66.67 \%$ of the $n$-alkanes were eliminated when compared to the control. The degradation rates of $n$-alkanes with different chain lengths were determined from the decreases in the peak areas of individual n-alkanes. Strain HJ4 exhibited higher degradation capacity than HJ2, and particularly showed higher degradation efficiency of long-chain n-alkanes (>37.00 min retention time), although the two strains had similar overall biodegradation rates of heavy oil (Table 2).

Generally, mesophilic microorganisms most readily degrade alkanes with carbon chain lengths ranging from 10 to 16 to generate energy for their growth; however, polycyclic aromatic hydrocarbons, which are less bioavailable than alkanes, are not completely degraded because they are more effectively partitioned into the heavier fractions of resin and asphaltene [22, 23]. In our study, A. terreus HJ2 and A. nidulans HJ4 showed the ability to degrade long alkyl chains and asphaltenes of heavy oil in aerobic conditions. Microbial degradation of heavy oil is a complex process that involves various types of enzymes, such as oxygenases, dehydrogenases and hydroxylases. These enzymes can catalyze aromatic and aliphatic hydroxidation, oxidative deamination, hydrolysis, and other biochemical transformations of substances in the original oil [12]. A test of in-vitro oil degradation by the crude enzymes demonstrated an accelerated biodegradation of aliphatic, aromatic, resin, and asphaltene fractions due to enhanced enzyme activities in the enzymatic co-culture [22]. Thus, we speculated that our Aspergillus isolates $\mathrm{HJ} 2$ and $\mathrm{HJ} 4$ produce multiple enzymes that can be directly used to degrade heavy oil.

\section{Enzymatic degradation of heavy oil}

\section{Enzymatic hydrocarbon degradation activity}

When grown on the enzyme-producing medium, strains HJ2 and HJ4 produced extracellular enzymes with dehydrogenase and C230 activities; the enzyme mixtures were designated E2 and E4, respectively. The average dehydrogenase activity of the extracellular enzymes was $66.76 \pm 0.25$ (E2) and $68.77 \pm 0.18$ (E4) $\mu \mathrm{g} \mathrm{g}^{-1} \mathrm{~min}^{-1}$. The $\mathrm{C} 230$ activity was $3.65 \pm 0.014$ (E2) and $4.32 \pm 0.028 \mu \mathrm{mol} \mathrm{min}^{-1} \mathrm{mg}^{-1}$. 
Dehydrogenase and C230 activities reflect the ability of microorganisms to degrade alkanes and aromatic hydrocarbons. The activities of the two fungal enzyme preparations suggested that they could be used directly for hydrocarbon degradation.

The chemical inertness of hydrocarbons poses an energetic and mechanistic challenge for microbial metabolism. This is particularly true for the initial activation and eventual cleavage of the apolar $\mathrm{C}-\mathrm{H}$ bond, where high energy barriers must be overcome, and, therefore, the rate of conventional biodegradation of hydrocarbons is relatively slow [24]. The enzyme preparations E2 and E4 are capable of degrading hydrocarbons and releasing biogas. Fig. 4 showed the cumulative gas production after $15 \mathrm{~d}$ with $2 \mathrm{~g}$ of hydrocarbon as the enzymatic substrate. During degradation, the maximum gas values for bituminous crude oil ( $15 \%, \mathrm{w} / \mathrm{w})$, heavy oil, light oil, wax, and liquid paraffin were 40.0-67.5, 64.0-80.5, 75.0-80.0, 81.0-109.5, and 73.0-76.0 mL bottle $\mathrm{e}^{-1}$, respectively, for E2 and E4. E4 showed higher gas production than E2, which implied higher degradation ability of hydrocarbons by E4 as compared to E2. Both enzyme mixtures showed higher efficacy in biodegrading wax and light oil than bituminous crude oil. According to Al-Sayegh et al. [25], due to being rich in resin and asphaltene, bituminous crude oil is relatively resistant to biodegradation and more slowly degraded than linear oils. The aliphatic fraction, which is more susceptible to degradation than the aromatic and asphaltene fractions, was probably more easily broken down by the enzyme mixtures E2 and E4. Based on the gas production results, which measure enzymatic hydrocarbon degradation activity, we inferred that the enzyme mixtures E2 and E4 can be used to enhance oil mobilization by degrading heavy oil and producing bioproducts.

\section{Effect of enzyme concentration on heavy oil degradation}

Evaluation of heavy oil degradation by different concentrations of crude enzymes in oxygen-deprived conditions showed positive results (Table 3). The four fractions of heavy oil were redistributed after $15 \mathrm{~d}$ of incubation at $40{ }^{\circ} \mathrm{C}$. As the crude enzyme concentration increased from $2 \%$ to $10 \%$, the content of saturates markedly decreased, with the percentages of degradation in the range of $16.28-27.61 \%$. The content of aromatics and resins first increased and then decreased, both of which remained higher than the control levels, by $30.85-64.89 \%$ and $2.45-28.82 \%$, respectively. By contrast, the content of asphaltenes decreased slightly by $2.97-13.86 \%$ compared with the control level. The observed trends in the four fractions of heavy oil indicate that enzyme concentration is a critical factor in determining the oil degradation rate.

The degradation efficiency of different heavy oil fractions by bacterial consortia was reported to be $10.57-23.68 \%$ for alkanes, $6.03-20.62 \%$ for aromatics, and $3.63-16.90 \%$ for resins and asphaltenes [10, 26, 27]. By comparison, the fungal enzyme preparations from our Aspergillus cultures had higher abilities to degrade saturates, while the aromatic hydrocarbon and resin fractions of heavy oil were relatively increased after degradation. According to Mohamed et al. [28], the primary consumption or depletion of the saturated fraction can result in high polyaromatic and asphaltene content, which are more recalcitrant to biodegradation. In MEOR, it is important to select appropriate strains that can survive and secret specific metabolic products under the reservoir conditions, yet it remains difficult to isolate microorganisms that can tolerate the geological environment of oil reservoirs. Therefore, the fungal enzyme preparations, which exhibit unique biodegradation capabilities and require no use of live microorganisms, are a good choice for MEOR.

The process of heavy oil degradation by the two enzyme preparations at different concentration was accompanied by dynamic production of gas. The total gas production varied from 25.5 to $100.0 \mathrm{~mL}$ bottle ${ }^{-1}$ for preparation E2 and 24.0 to $186.5 \mathrm{~mL}$ bottle $\mathrm{e}^{-1}$ for E4 (Table 3). GC analysis indicated that these gases were mainly $\mathrm{CO}_{2}$ and $\mathrm{H}_{2}$ with small amounts of methane. Production of gas showed significant correlations with the amount of enzyme $(P<0.05)$. The correlation coefficients were 0.93984 and 0.99569 , respectively. The gas produced by enzymatic degradation can contribute to enhanced heavy oil recovery by increasing the pressure of the reservoir and reducing oil viscosity.

\section{Effect of surfactants on heavy oil degradation}

Surfactants are amphiphilic compounds which partition at the interface between fluid phases with various polarities. Surfactants decrease interfacial and superficial tensions of solutions and facilitate the bioavailability of hydrophobic chemicals by solubilization and emulsification [29]. The effects of surfactants of both biological and chemical origin on the enzymatic degradation of heavy oil by E2 and E4 were measured in degradation assays. In the control group (without crude enzyme solution), gravitational analysis of $2 \mathrm{~g}$ heavy oil showed a content of: saturates, $1567 \mathrm{mg}$; aromatics, $274 \mathrm{mg}$; resin, $157 \mathrm{mg}$; and asphaltene, $101 \mathrm{mg}$. After $15 \mathrm{~d}$ of enzymatic degradation, the content of saturates was decreased to $1327 \mathrm{mg}$ (E2), $1353 \mathrm{mg}$ (EB2), $1321 \mathrm{mg}$ (EC2), $1294 \mathrm{mg}$ (E4), $1371 \mathrm{mg}$ (EB4), and $1272 \mathrm{mg}$ (EC4), respectively; the content of aromatics was increased to $417 \mathrm{mg}$ (E2), $352 \mathrm{mg}$ (EB2), $330 \mathrm{mg}$ (EC2), $440 \mathrm{mg}$ (E4), $372 \mathrm{mg}$ (EB4), $371 \mathrm{mg}$ (EC4), respectively; the content of asphaltenes was slightly decreased to 93-97 mg; and the resins were increased to 181-233 mg by the two enzymes but decreased from $147-104 \mathrm{mg}$ if surfactants were also added. The biogas yield was reduced from 67.0 to $50.0 \mathrm{~mL}$ bottle ${ }^{-1}$

Page $4 / 20$ 
and 86.5 to $56.5 \mathrm{~mL}$ bottle ${ }^{-1}$, respectively, for crude enzyme preparations E2 and E4 on addition of the biosurfactants and SDS (Table 4). The results show that addition of surfactant had an inhibitory effect on the enzymatic degradation of heavy oil. It has been reported that many surfactants are antimicrobial, and the antimicrobial activity depends on the surfactant concentration and the strain used for biodegradation [30]. Sajna et al. [31] and Tian et al. [32] reported that most surfactants exhibit toxicity to microorganisms at above 1 critical micelle concentration, which influences cell surface properties and metabolic pathways, then results in a decrease in the crude oil biodegradation rate.

\section{Enzymatic degradation of gasifiable n-alkanes}

Enzymatic degradation had a significant effect on the relative quantities of gasifiable $n$-alkanes compared with controls. More detailed assessment of the variation of $n$-alkanes can be found in Table 2. The two enzyme preparations caused apparent increases in the total number of gasifiable $n$-alkanes, and 11-13 new fractions appeared, while three fractions disappeared relative to the control. Correspondingly, the overall total peak area of gasifiable $n$-alkanes was increased by $91.77 \%$ (E2) and $130.73 \%$ (E4). Both enzyme preparations showed higher degradation efficacy for long-chain alkanes. The increase of peak area of individual $n$-alkanes was 11.46 to $198.19 \%$ (E2) and 15.16 to $537.41 \%$ (E4). This variation of the oil components, especially the decrease of long-chain fractions of saturated hydrocarbons, has positive effects on the physicochemical properties of the heavy oil, such as light component increase, viscosity reduction, and fluidity enhancement.

Degradation of heavy fractions is considered one of the main mechanisms of MEOR by which the oil's viscosity and freezing point are reduced, which in turn will increase the oil's mobility in situ [33]. It has been reported that numerous functional microbes (e.g., Petrobacter sp., Enterobactersp., Bacillus sp., and Geobacillus sp.) can produce highly degradative enzymes, resulting in the breakdown of hydrocarbon chains, making them lighter and enhancing oil mobility $[34,35]$. In the present study, the two tested fungal enzyme preparations showed strong abilities to degrade heavier fractions into lighter fractions in oxygen-deprived conditions. Although the exact mechanism is not known, the fungal enzymes might specifically shorten long chain hydrocarbons, depolymerize asphaltenes and increase the solvent fraction, which would benefit heavy oil recovery.

\section{Viscosity reduction of heavy oil}

High viscosity is an important factor responsible for poor heavy oil recovery [36]. Conventional methods for reducing oil viscosity, such as heating, emulsification, and dilution with light crude oil, have the disadvantages of high cost in application and potential damage to the formation. In this study, the potential use of fungal enzyme preparations to reduce oil viscosity was, therefore, examined. The two fungal enzyme preparations were able to reduce the viscosity of heavy oil from 29,700 to 13,700 , and $10,000 \mathrm{mPa}$ s, respectively. E4 had greater viscosity reduction efficiency $(66.33 \%)$ than E2 (53.87\%). Previous studies have shown that some bacterial strains (e.g., Bacillus subtilis, $B$. licheniformis, and Geobacillus stearothermophilus) reduce heavy oil viscosity by $15.47-40.06 \%$ under aerobic and aerobic conditions [26, 27]. Compared with these bacteria, the fungal enzyme preparations exhibited markedly higher abilities to decrease heavy oil viscosity in the current study. Moreover, enzyme preparations have the advantage of short heavy oil degradation time and they do not require the use of live microorganisms, which is conducive to use in heavy oil reservoirs with poor growth of oxygen-consuming microorganisms in situ. The high contents of long-chain hydrocarbons with a complex structure, heteroatoms (e.g., O, N, S and metals), and asphaltenes in heavy oil lead to its high viscosity [37]. Moreover, these adverse conditions usually have negative effects on biodegradation of the oil. However, the fungal enzyme preparations used in our study exhibited the ability to decompose long-chain alkanes and heavy fractions (e.g., asphaltene), leading to a decrease of average molecular weight and reduction of heavy oil viscosity.

\section{Removal of heavy crude oil from sand}

Table 5 shows the amount of heavy oil removed from artificially contaminated sand after treatment with crude enzyme solution. The removal efficiencies of the two crude enzyme solutions (E2 and E4) ranged from 7.85 to $8.48 \%$, that is, 2.29-2.47-fold that of the control (3.43\%). Fig. 5 shows the removal efficiency of heavy oil adsorbed on sand by the crude enzyme solution. The fungi in our study showed lower ability to produce biosurfactants than some bacteria (e.g., B. subtilis and $P$. aeruginosa). The diameter of oil spreading from the crude enzyme solutions reached only $12.0-13.0 \mathrm{~cm}$ (the oil spreading experiment was carried out according to the method described by Zhang et al. [16]). Biosurfactants are known as a promising agent for enhancing oil recovery, have been successfully applied in oilfield exploitation $[38,39]$. França et al. [40] obtained that the cell-free fermented broth of $B$. subtilis ICA56 containing biosurfactant removed $85 \%$ of crude oil, which highlighted the crucial role of biosurfactant for the cleaning process. Thus, the crude enzyme solutions (low content of biosurfactants) were insufficient to mobilize a significant amount of entrapped oil.

Page 5/20 
The removal effects of the two crude enzyme solutions were possibly due to heavy component degradation and gas production. The interactions of gas with oil, as well as the bioconversion of heavy oil fractions to lighter fractions, are mechanisms responsible for increasing the mobility and recovery of heavy oil [34]. Xia et al. [10] reported that one enriched methanogenic consortium increased by $14.7 \%$ of the tertiary enhanced oil recovery by oil degradation and methane production in core flooding tests, and the gas production made the inner pressure of the microbial core holder increase from 0.2 to $20.45 \mathrm{MPa}$; the viscosity of the heavy oil was reduced by $72.45 \%$.

Biodegradation in oil reservoirs affects the quantity and quality of the crude oil; crude oil will become lighter and more valuable by degrading heavy oil fractions [36]. Our results suggest that supplementation with biosurfactants after enzyme solution flooding may be an more effective strategy to improve heavy oil recovery than pure enzyme solution flooding.

\section{Conclusions}

Two pure cultures A. terreus and A. nidulans, which were isolated from bitumen samples, exhibited high heavy oil biodegradation capacity. Crude enzyme preparations from the two fungal strains showed effective heavy oil degradation. Both enzyme preparations efficiently degraded different oil fractions, showed their best degradation activity toward high-molecular-weight alkanes, and reduced oil viscosity, with concurrent production of gases. The fungal enzyme preparations exhibited great potential in the cracking of heavy oil, which could improve the crude oil quality. Additionally, enzyme preparation showed positive effects in the removal of heavy oil by heavy component degradation and gas production. This study demonstrates the potential feasibility of fungal enzyme preparations for use in the improvement of quality of crude oil and enhanced heavy oil recovery. The application of fungal enzymes in oil recovery is a novel, environmentally-friendly, low-cost strategy.

\section{Methods}

\section{Media, heavy oil, and bitumen}

Mineral salts medium ( $\mathrm{pH} 7.0$ ) contained $\left(\mathrm{g} \mathrm{L}^{-1}\right)$ : $\mathrm{KNO}_{3}, 5.0 ; \mathrm{MgSO}_{4} \cdot 7 \mathrm{H}_{2} \mathrm{O}, 0.5$; and $\mathrm{KH}_{2} \mathrm{PO}_{4}, 1.0$. Enrichment medium was prepared by supplementing $20 \%(\mathrm{w} / \mathrm{v})$ potato juice with $2 \%(\mathrm{v} / \mathrm{v})$ heavy oil as sole carbon source. Heavy oil was obtained from Yanchang Oilfield, Shaanxi Province, China. Potato dextrose agar (PDA) consisted of $20 \%(\mathrm{w} / \mathrm{v})$ potato juice, $1 \%(\mathrm{w} / \mathrm{v})$ cane sugar, and $1 \%(\mathrm{w} / \mathrm{v})$ agar. The enzyme-producing medium contained mineral salts solution, wheat bran, and heavy oil $\left(80: 100: 2, \mathrm{v} \mathrm{g}^{-1} \mathrm{~g}^{-1}\right)$. Bitumen samples were obtained from BAOLIRUS International Investment Co., Ltd. (Yangling, Shaanxi, China).

\section{Fungal isolation and identification}

Fungi were isolated through the enrichment method. About $10 \mathrm{~g}$ of bitumen sample was transferred to a $250-\mathrm{mL}$ saline bottle containing $100 \mathrm{~mL}$ of enrichment medium and incubated at $30^{\circ} \mathrm{C}$ without shaking for $7 \mathrm{~d} ; 10 \mathrm{~mL}$ of the enrichment liquid was then transferred to fresh enrichment medium and cultured in the same conditions for another $7 \mathrm{~d}$. After the third subculture, the enrichment culture broth was serially diluted to $10^{-3}$ dilution; $50 \mu \mathrm{L}$ of sample from each dilution was spread on PDA plates and incubated at $30^{\circ} \mathrm{C}$ in aerobic conditions. Morphologically different colonies were picked and purified by using the dilution separation method on fresh PDA plates. Fungal cultures were identified by morphological examination and gene sequencing [12]. Spore structure of fungal cultures was observed using an S-4800 field emission scanning electron microscope (Hitachi, Tokyo, Japan). For molecular identification, DNA from isolated cultures was extracted and the rDNA-ITS gene was amplified by PCR using primers ITS1 (5'-CTTGGTCATTTAGAGGAAGTAA-3') and ITS4 (5'-

TCCTCCGCTTATTGATATGC-3'). Purified products were directly sequenced and assembled and then preliminarily compared with sequence data from the GenBank database of NCBI (http://www.ncbi.nlm.nih.gov) using the BLAST service to determine their approximate phylogenetic affiliations. A phylogenetic tree was constructed in MEGA 6.0 software using rDNA-ITS sequences of the fungal isolates and their close relatives in the GenBank database.

\section{Fungal degradataion of heavy oil}

The heavy oil biodegradation ability of isolated fungal cultures was tested initially by evaluating the growth of fungi on oil and bitumen plates. The pure cultures were previously activated by transferring cultures from PDA slants into PDA liquid medium with shaking at $100 \mathrm{rpm}$ for $5 \mathrm{~d}$ at $30^{\circ} \mathrm{C}$. Mycelial pellets were inoculated onto oil and bitumen plates containing the mineral salts medium (per liter mineral salts solution, with $20 \mathrm{~g}$ of heavy oil and bitumen, respectively), and incubated at $30^{\circ} \mathrm{C}$ for $5-7 \mathrm{~d}$. The growth of each strain was observed and photographed. Cultures with good growth on oil and bitumen plates were chosen as the experimental strains for further degradation of heavy oil. 
For degradation experiments, a $2.00 \mathrm{~g}$ portion of heavy crude oil from the Yanchang Oilfield (as the sole carbon source) was mixed with $150 \mathrm{~mL}$ potato juice $(20 \%, \mathrm{w} / \mathrm{v})$ in a $600-\mathrm{mL}$ tissue culture vessel. One loop of pure fungal culture was taken from the PDA slant and transferred into the potato juice/crude oil mixture; the culture was incubated at $30^{\circ} \mathrm{C}$ for $15 \mathrm{~d}$. Control tests used sterile potato juice and heavy oil without microorganism inoculation. After incubation, the residual oil was extracted from the $150 \mathrm{~mL}$ culture solution with $100 \mathrm{~mL}$ $\mathrm{n}$-hexane. Then, $1.5 \mathrm{~mL}$ of the $\mathrm{n}$-hexane containing residual oil was analyzed by gas chromatography (GC) followed by gravimetric analysis to evaluate the degradation efficiency according to a published method [41]. Then, the heavy oil after degradation efficiency measurement was redissolved in $100 \mathrm{~mL} \mathrm{n}$-hexane and left $24 \mathrm{~h}$ for asphaltene precipitation. The precipitate was collected by centrifugation at 5,000 $\times \mathrm{g}$ for $5 \mathrm{~min}$, oven-dried at $40^{\circ} \mathrm{C}$ for $24 \mathrm{~h}$ and quantified gravimetrically. Fractions of the organic phase were further distinguished into saturates, aromatics, and resin by loading onto an $\mathrm{Al}_{2} \mathrm{O}_{3}$ column and eluting with several different developing solvents ( $\mathrm{n}$-hexane, $\mathrm{n}$ hexane/dichloromethane [3:1, v/v], absolute ethyl alcohol), followed by gravimetric analysis. The degradation efficiency for heavy oil and four fractions $\left(\mathrm{VR}_{\mathrm{m}} \%\right)$ was defined as the ratio of fungal degradation to the initial heavy oil and four fractions, as shown in the following formula:

$$
V R_{m} \%=\frac{M_{c t r 1}-M_{-}}{M_{c t r l}} \times 100
$$

where $\mathrm{M}_{\mathrm{Ctrl}}$ and $\mathrm{M}_{\mathrm{s}}$ are the masses of heavy oil and four fractions (alkanes, aromatics, resins, and asphaltenes) in the control and fungaldegraded samples, respectively .

\section{Enzymatic degradation of heavy oil}

\section{Enzymatic activities assay}

Fungal crude enzyme preparations were formulated as previously reported [16]. All fungal spores formed in one PDA slant were inoculated into $50 \mathrm{~g}$ of enzyme-producing medium and incubated for $5 \mathrm{~d}$ at $30^{\circ} \mathrm{C}$. Subsequently, the medium containing extracellular enzymes and fungal cells was placed in a ventilated place to dry to $30 \%$ moisture content and then oven-dried at $40{ }^{\circ} \mathrm{C}$ for $48 \mathrm{~h}$. The dried medium was ground into powder and passed through a $0.10-\mathrm{mm}$ sieve to obtain powdered enzyme preparations. The crude enzyme solution used in experiments was prepared by following the steps below: $4.000 \mathrm{~g}$ solid enzyme preparation was dissolved in $100 \mathrm{~mL}$ of distilled water in a 250-mL conical flask, oscillated at $30^{\circ} \mathrm{C}$ with shaking at $100 \mathrm{rpm}$ for $15 \mathrm{~h}$, and then filtered through sterile fiberglass to obtain the crude enzyme solution.

The dehydrogenase and catechol 2,3-dioxygenase (C230) activities of fungal enzyme preparations were assayed using a UV-vis spectrophotometer (UV-1800, MAPADA, Shanghai) by increases in absorbance at specific wavelengths. Dehydrogenase activity was measured by the triphenyltetrazolium chloride colorimetric method described by Jafari et al. [42]. C230 activity was assayed based on the procedure reported by Yanto and Tachibana [12]. Enzymatic activity experiments were carried out in a water bath at $37^{\circ} \mathrm{C}$. The dehydrogenase activity was calculated according to a calibration curve prepared using triphenyl formazan and was expressed in terms of the amount of triphenyl formazan produced per gram of enzyme preparation per min. The C230 activity was expressed in units per milligram $\left(\mathrm{U} \mathrm{mg}^{-1}\right)$, where one enzyme unit $(U)$ was defined as the amount forming $1.0 \mu \mathrm{mol}$ of 2-hydroxymuconic semialdehyde per min in the assay conditions.

\section{Enzymatic hydrocarbon degradation activity}

The hydrocarbon substrates included bituminous crude oil ( $15 \%$ w/w), heavy oil, light oil, wax, and liquid paraffin. The experiment was conducted in a 100-mL saline bottle supplemented with $30 \mathrm{~mL}$ of crude enzyme solution; $2 \mathrm{~g}$ of each hydrocarbon substrate was added respectively, and then the saline bottles were sealed with rubber stoppers. Incubation was carried out at $40^{\circ} \mathrm{C}$ for $15 \mathrm{~d}$ with shaking once per day throughout the incubation period. Enzymatic hydrocarbon degradation activity was evaluated by measuring gas production. The gas produced was captured using a $100-\mathrm{mL}$ glass syringe. Because the pressure inside the bottle had increased with gas production, the syringe filled spontaneously. The total amount of gas produced was recorded.

\section{Effect of enzyme concentration on heavy oil degradation}

Different concentrations $(2.0,4.0,5.0,6.0,8.0$, and $10 \mathrm{~g})$ of solid enzyme preparations were respectively weighed into $250-\mathrm{mL}$ conical flasks containing $100 \mathrm{~mL}$ of distilled water, oscillated at $120 \mathrm{rpm}$ at $30^{\circ} \mathrm{C}$ for $15 \mathrm{~h}$, and then filtered through sterile fiberglass to obtain $2,4,5,6,8$, and $10 \%$ enzyme solutions. Enzymatic degradation of heavy oil was performed in 100-mL saline bottles containing $2 \mathrm{~g}$ of heavy oil and

Page 7/20 
$30 \mathrm{~mL}$ of crude enzyme solution; the bottles were sealed with rubber stoppers. The reaction solutions were incubated at $40{ }^{\circ} \mathrm{C}$ for $15 \mathrm{~d}$ with shaking once per day throughout the incubation period. Controls were prepared by adding $30 \mathrm{~mL}$ of distilled water instead of crude enzyme solution. After enzymatic degradation, the amount of gas produced was recorded and the gas components were identified by GC [16], and then the residual oil was extracted with n-hexane and analyzed by $\mathrm{Al}_{2} \mathrm{O}_{3}$ column chromatography.

\section{Effect of surfactants on enzyme activity}

Pure culture of B. amyloliquefaciens isolated by our laboratory from an oil-contaminated soil sample was pre-cultured in a 600 -mL tissue culture vessel containing $100 \mathrm{~mL}$ of fermentation medium at $30{ }^{\circ} \mathrm{C}$ with shaking (100 rpm) for $7 \mathrm{~d}$ [43]. The sample was centrifuged at $10,000 \times \mathrm{g}$ for $10 \mathrm{~min}$ at $4{ }^{\circ} \mathrm{C}$ to obtain the cell-free supernatant. To evaluate the effects of the addition of surfactant on heavy oil degradation, assays were performed in sealed 100-mL saline bottles containing $2 \mathrm{~g}$ of heavy oil plus $30 \mathrm{~mL}$ of reaction solution. The reaction solutions included: (i) $30 \mathrm{~mL}$ crude enzyme solution (4\% w/v); (ii) $15 \mathrm{~mL}$ crude enzyme solution (8\% w/v) +15 mL bacterial fermentation broth containing biosurfactant (final concentration of crude enzyme 4\%); or (iii) $15 \mathrm{~mL}$ crude enzyme solution (4\% w/v final concentration) $+15 \mathrm{~mL}$ sodium dodecyl sulfate (SDS, chemically pure, $1 \mathrm{mg} \mathrm{mL}^{-1}$ ). Control samples were prepared in the same way without the addition of crude enzyme solution. The bottles were incubated at $40{ }^{\circ} \mathrm{C}$ for $15 \mathrm{~d}$. The effect of the addition of surfactant on heavy oil degradation was evaluated by measuring gas production coupled with residual oil fraction analysis.

\section{Gas chromatographic analysis of heavy oil}

Residual oil was extracted from culture fluid and reaction solutions with $100 \mathrm{~mL} n$-hexane using the protocols described in Sect. 2.3. $\mathrm{n}$ Hexane extract $(1.0 \mu \mathrm{L})$ was analyzed using a Thermo Finnigan Trace GC Ultra (San Francisco, CA, USA) equipped with a flame ionization detector and a DB-Wax capillary column (30 $\mathrm{m} \times 0.25 \mathrm{~mm} \times 0.25 \mu \mathrm{m})$. The carrier gas was nitrogen. The injector and detector temperatures were maintained at 240 and $280^{\circ} \mathrm{C}$, respectively. The column was programmed with an initial temperature of $40{ }^{\circ} \mathrm{C}$, held for 2 min, then heated to $240{ }^{\circ} \mathrm{C}$ at $6^{\circ} \mathrm{C} \mathrm{min}-1$, then held for $8 \mathrm{~min}$. n-Alkane degradation was evaluated by comparing the difference in the chromatographic peak areas of the hydrocarbons recovered after treatment with those of the hydrocarbons recovered from abiotic control samples at the same retention time. Relative variations $\left(\mathrm{VR}_{\mathrm{a}} \%\right)$ in the chromatographic peak area of each $\mathrm{n}$-alkane fraction were calculated as:

$$
V R_{a} \%=\frac{A_{C \text { trl }}-A_{s}}{A_{c t r l}} \times 100
$$

where $A_{c k}$ is the chromatographic peak area of the individual n-alkane fraction from the control and $A_{s}$ is the chromatographic peak area of the individual n-alkane fraction after treatment.

\section{Viscosity measurement of heavy oil}

Changes in the viscosity of heavy oil with enzymatic degradation were measured using an NDJ79 rotating viscometer (Yutong, Shanghai, China) at $50{ }^{\circ} \mathrm{C}$ and atmospheric pressure ( $\left.0.1 \mathrm{MPa}\right)$. Heavy oil viscosity was compared between enzymatically-degraded and control samples. The viscosity reduction rate (VRR\%) of heavy oil was calculated as:

$$
V R R \%=\frac{V_{C t r 1}-V_{s}}{V_{C t r l}} \times 100
$$

where $V_{c k}$ and $V_{s}$ represent the viscosities of heavy oil recovered from the control and enzymatically-degraded samples, respectively.

\section{Removal of heavy oil from sand}

A custom-designed oil removal experiment using artificially contaminated sand was conducted to test the efficacy of the crude enzyme preparations in heavy oil recovery. The sand, $0.25-0.50 \mathrm{~mm}$ fractions, was taken from the Weihe River. Enzyme injections: $150 \mathrm{~mL}$ of crude enzyme solution ( $4 \% \mathrm{w} / \mathrm{v}$ ) was added to a $600-\mathrm{mL}$ tissue culture vessel containing $90 \mathrm{~g}$ of sand contaminated with $10 \%$ crude oil, then incubated at $40{ }^{\circ} \mathrm{C}$ for $9 \mathrm{~d}$. Control samples were prepared in the same way, with the addition of $150 \mathrm{~mL}$ distilled water. After $9 \mathrm{~d}$ in total of static incubation at $40{ }^{\circ} \mathrm{C}$ in the dark, the mixtures were filtered through sterile cotton wool to separate the sand and heavy oil. The heavy oil- 
covered sterile cotton wool was extracted with $150 \mathrm{~mL} n$-hexane, dried by vacuum-rotary evaporation at $40^{\circ} \mathrm{C}$, cooled to ambient temperature and then weighed $(m)$. The heavy oil removal efficiency (RE\%) was calculated as:

$$
R E \%=\frac{M}{10} \times 100
$$

where $\mathrm{M}$ is the mass $(\mathrm{g})$ of heavy oil removed from the artificially contaminated sand after treatment, and $10(\mathrm{~g})$ is the original mass of the heavy oil.

\section{Statistical analysis}

All experiments were performed in triplicate. Data are expressed as the mean \pm standard deviation $(n=3)$. Comparison of group mean values to obtain significant differences was conducted using Duncan's test. All analyses were performed at $\mathrm{P}<0.05$ using SAS 9.2 software (SAS Institute Inc., Cary, NC, USA).

\section{Declarations}

\section{Acknowledgements}

The study was financially supported by the National Natural Science Foundation (No.51904267) in P.R. China and Tianchi Doctorate Program Foundation (No.042312048). Gas chromatography data was acquired in the Laboratory of the College of Forestry, Northwest A \& F University (Yangling, Shaanxi Province, China). We thank Dr. Hang Yu (College of Forestry, Northwest A \& F University) for technical assistance.

\section{Authors'contributions}

$\mathrm{JHZ}$ carried out the experiments, analyzed the data and drafted the manuscript. QHX and SBH conceived and supervised the study and reviewed the final manuscript. HG assisted in fungal isolation and identification experiments. HXL took oil-contaminated soils and heavy oil samples, and participated in the design of the study and coordination. All authors read and approved the final manuscript.

\section{Funding}

The study was supported by the National Natural Science Foundation (No.51904267) in P.R. China and Tianchi Doctorate Program Foundation (No.042312048).

\section{Ethics approval and consent to participate}

Not applicable.

\section{Consent for publication}

Not applicable.

\section{Competing interests}

The authors declare that they have no competing interests.

\section{Author details}

${ }^{1}$ College of Resource and Environment Sciences, Key Laboratory of Oasis Ecology of Education Ministry, Xinjiang University, Urumqi 830046, China

${ }^{2}$ College of Natural Resources and Environment, Northwest A \& F University, Yangling 712100, China

\section{References}

1. Shibulal B, Al-Bahry SN, Al-Wahaibi YM, Elshafie AE, Al-Bemani AS, Joshi SJ. Microbial enhanced heavy oil recovery by the aid of inhabitant spore-forming bacteria: an insight review. Sci World J. 2014;2014:1-12. 
2. Martínez-Palou R, Mosqueira ML, Zapata-Rendón B, Mar-Juárez E, Bernal-Huicochea C, Clavel-López JC, Aburto J. Transportation of heavy and extra-heavy crude oil by pipeline: a review. J Petrol Sci Eng. 2011;75:274-82.

3. Guo K, Li HL, Yu ZX. In-situ heavy and extra-heavy oil recovery: a review. Fuel. 2016;185:886-902.

4. Shah A, Fishwick R, Wood J, Leeke G, Rigby S, Greaves M. A review of novel techniques for heavy oil and bitumen extraction and upgrading. Energy Environ Sci. 2010;3:700-14.

5. Safdel M, Amin AM, Daryasafar A, Jamialahmadi M. Microbial enhanced oil recovery, a critical review on worldwide implemented field trials in different countries. Renew Sust Energ Rev. 2017;74:159-72.

6. Sen R. Biotechnology in petroleum recovery: the microbial EOR. Prog. Energy Combust Sci. 2008;34:714-24.

7. Gudiña EJ, Teixeira JA. HC-0C-03: Biological treatments to improve the quality of heavy crude oils. In: Heimann K., Karthikeyan O., Muthu S. (eds). Biodegradation and bioconversion of hydrocarbons. Environmental Footprints and Eco-design of Products and Processes. Springer, Singapore. 2017.

8. Van Hamme JD, Singh A, Ward OP. Recent advances in petroleum microbiology. Microbiol Mol Biol Rev. 2003;67:503-49.

9. Márcia RC, Eduardo JG, Débora F, José AT, Lígia RR. The biopolymer produced by Rhizobium viscosum CECT 908 is a promising agent for application in microbial enhanced oil recovery. New BIOTECHNOL. 2019;49:144-50.

10. Xia WJ, Shen WJ, Yu L, Zheng CG, Yu WC, Tang YC. Conversion of petroleum to methane by the indigenous methanogenic consortia for oil recovery in heavy oil reservoir. Appl Energ. 2016;171:646-55.

11. Kumari B, Singh SN, Singh DP. Characterization of two biosurfactant producing strains in crude oil degradation. Process Biochem. 2012;47:2463-71.

12. Yanto DHY, Tachibana S. Potential of fungal co-culturing for accelerated biodegradation of petroleum hydrocarbons in soil. $\mathrm{J}$ Hazard Mater. 2014;278:454-63.

13. Haritas AK, Kaushik CP. Biodegradation aspects of polycyclic aromatic hydrocarbons (PAHs): a review. J Hazard Mater. 2009;169:1-15.

14. Chikere CB, Okpokwasili GC, Chikere BO. Monitoring of microbial hydrocarbon remediation in the soil. 3 Biotech. 2011;1:117-38.

15. Zhang JH, Xue QH, Gao H, Wang P. Biodegradation of paraffin wax by crude Aspergillus enzyme preparations for potential use in removing paraffin deposits. J Basic Microb. 2015;55:1-10.

16. Zhang JH, Xue QH, Gao H, Ma X, Wang P. Biodegradation of crude oil by fungal enzyme preparations from Aspergillus for potential use in enhanced oil recovery. J Chem Technol Biotechnol. 2016;91:865-75.

17. Patel J, Borgohain S, Kumar M, Rangarajan V, Somasundaran P, Sen R. Recent developments in microbial enhanced oil recovery. Renew Sust Energ Rev. 2015;52:1539-58.

18. Nemati M, Voordouw G. Modification of porous media permeability, using calcium carbonate produced enzymatically in situ. Enzyme Microb Technol. 2003;33:635-42.

19. Kong J, Li HB, Zhou ML, Gai HF. Enzyme base reservoir blockage removing agent SUN and its uses in Shengli offshore oil fields. Oilfield Chem. 2005;22:23-4.

20. Ayala M, Verdín J, Vazquez-Duhalt R. The prospects for peroxidase-based biorefining of petroleum fuels. Biocatal Biotransfor. 2007;25:114-29.

21. Chaillan F, Flèche AL, Bury E, Phantavong YH, Grimont P, Saliot A, Oudot J. Identification and biodegradation potential of tropical aerobic hydrocarbon-degrading microorganisms. Res Microbiol. 2004;155:587-95.

22. Kato T, Haruki M, Imanaka T, Morikawa M, Kanaya S. Isolation and characterization of long-chain-alkane degrading Bacillus thermoleovorans from deep subterranean petroleum reservoirs. J Biosci Bioeng. 2001;91:64-70.

23. Yanto DHY, Tachibana S. Enhanced biodegradation of asphalt in the presence of Tween surfactants, $\mathrm{Mn}^{2+}$ and $\mathrm{H}_{2} \mathrm{O}_{2}$ by $P e s t a l o t i o p s i s$ in liquid medium and soil. Chemosphere. 2014;103:105-13.

24. Moussavi G, Shekoohiyan S, Naddafi K. The accelerated enzymatic biodegradation and COD removal of petroleum hydrocarbons in the SCR using active bacterial biomass capable of in-situ generating peroxidase and biosurfactants. Chem Eng J. 2017;308:1081-9.

25. Al-Sayegh A, Al-Wahaibi Y, Al-Bahry S, Elshafie A, Al-Bemani A, Joshi S. Microbial enhanced heavy crude oil recovery through biodegradation using bacterial isolates from an Omani oil field. Microb Cell Fact. 2015;14:141-52.

26. Sun SS, Luo YJ, Zhou Y, Xiao M, Zhang ZY, Hou J, Wei XF, Xu QS, Sha T, Dong H, Song H, Zhang ZZ. Application of Bacillus in pilot test of microbial huff and puff to improve heavy oil recovery. Energ Fuel. 2017;31:13724-32.

27. Zhou JF, Gao PK, Dai XH, Cui XY, Tian HM, Xie JJ, Li GQ, Ma T. Heavy hydrocarbon degradation of crude oil by a novel thermophilic Geobacillus stearothermophilus strain A-2. Int Biodeter Biodegr. 2018;126:224-30. 
28. Mohamed ME, Al-Dousary M, Hamzah RY, Fuchs G. Isolation and characterization of indigenous thermophilic bacteria active in natural attenuation of bio-hazardous petrochemical pollutants. Int Biodeter Biodegr. 2006;58:213-23.

29. Sakthipriya N, Doble M, Sangwai JS. Action of biosurfactant producing thermophilic Bacillus subtilis on waxy crude oil and long chain paraffins. Int Biodeter Biodegr. 2015;105:168-77.

30. Kitamoto D, Yanagishita H, Shinbo T, Nakane T, Kamisawa C, Nakahara T. Surface active properties and antimicrobial activities of mannosylerythritol lipids as biosurfactants produced by Candida Antarctica. J Biotechnol. 1993;29:91-6.

31. Sajna KV, Sukumaran RK, Gottumukkala LD, Pandey A. Crude oil biodegradation aided by biosurfactants from Pseudozyma NII08165 or its culture broth. Bioresour Technol. 2015;191:133-9.

32. Tian W, Yao J, Liu RP, Zhu MJ, Wang F, Wu XY, Liu HJ. Effect of natural and synthetic surfactants on crude oil biodegradation by indigenous strains. Ecotox Environ Safe. 2016;129:171-9.

33. She YH, Shu FC, Zhang F, Wang ZL, Kong SQ, Yu LJ. The enhancement of heavy crude oil recovery using bacteria degrading polycyclic aromatic hydrocarbons. Adv Mater Res. 2012;365:320-5.

34. Castorena-Cortés G, Roldán-Carrillo T, Reyes-Avila J, Zapata-Peñasco I, Mayol-Castillo M, Olguín-Lora P. Coreflood assay using extremophile microorganisms for recovery of heavy oil in Mexican oil fields. J Biosci Bioeng. 2012;114:440-5.

35. Zhang F, She YH, Banat IM, Chai LJ, Yi SJ, Yu GM, Hou DJ. Potential microorganisms for prevention of paraffin precipitation in a hypersaline oil reservoir. Energ Fuel. 2014;28:1191-7.

36. Ding MS, Zhang Y, Liu J. Application of microbial enhanced oil recovery technology in water-based bitumen extraction from weathered oil sands. AIChE J. 2014;60:2985-93.

37. Chen Q, Gao Y, Wang ZX, Guo AJ. Application of coker gas oil used as industrial hydrogen donors in visbreaking. Pet Sci Technol. 2014;32:2506-11.

38. Varjani SJ, Upasani VN. Core Flood study for enhanced oil recovery through ex-situ bioaugmentation with thermo- and halo-tolerant rhamnolipid produced by Pseudomonas aeruginosa NCIM 5514. Bioresour Technol. 2016;220:175-82.

39. de Araujo LLGC, Sodré LGP, Brasil LR, Domingos DF, de Oliveira VM, da Cruz GF. Microbial enhanced oil recovery using a biosurfactant produced by Bacillus safensis isolated from mangrove microbiota-Part I biosurfactant characterization and oil displacement test. $J$ Petrol Sci Eng. 2019;180:950-7.

40. França ÍWL, Lima AP, Lemos JAM, Lemos CGF, Melo VMM, Sant'ana HB, Gonçalves LRB. Production of a biosurfactant by Bacillus subtilis ICA56 aiming bioremediation of impacted soils. Catal Today. 2015;255:10-5.

41. Mishra S, Jyoti J, Kuhad RC, Lal B. In situ bioremediation potential of an oily sludge-degrading bacterial consortium. Curr Microbiol. 2001;43:328-35.

42. Jafari SJ, Moussavi G, Yaghmaeian K. High-rate biological denitrification in the cyclic rotating-bed biological reactor: effect of, nitrate concentration and salinity and the phylogenetic analysis of denitrifiers. Bioresour Technol. 2015;197:482-8.

43. Zhang JH, Lai HX, Gao H, Hu SB, Xue QH. Prevention and mitigation of paraffin deposition by biosurfactant-producing and paraffindegrading Bacillus amyloliquefaciens strain 6-2c. Chem Eng J. 2018;335:510-9.

\section{Tables}

Table 1 The four fractions of heavy oil before and after fungal treatment

\begin{tabular}{|c|c|c|c|c|c|c|c|c|c|c|}
\hline \multirow[t]{2}{*}{ Sample } & \multicolumn{2}{|l|}{ Heavy oil } & \multicolumn{2}{|l|}{ Alkanes } & \multicolumn{2}{|l|}{ Aromatics } & \multicolumn{2}{|l|}{ Resins } & \multicolumn{2}{|l|}{ Asphaltenes } \\
\hline & (mg) & $V R_{m} \%$ & $\left(\mathrm{mg} 2 \mathrm{~g}^{-1}\right)$ & $V R_{m} \%$ & $\left(\mathrm{mg} 2 \mathrm{~g}^{-1}\right)$ & $V R_{m} \%$ & $\left(\mathrm{mg} 2 \mathrm{~g}^{-1}\right)$ & $V R_{m} \%$ & $\left(\mathrm{mg} 2 \mathrm{~g}^{-1}\right)$ & $V R_{m} \%$ \\
\hline Ctrl & $1977 \pm 4^{\mathrm{a}}$ & - & $1589 \pm 25^{a}$ & - & $259 \pm 11^{a}$ & - & $150 \pm 1^{b}$ & - & $101 \pm 2^{a}$ & - \\
\hline HJ2 & $1477 \pm 13^{b}$ & -25.29 & $1014 \pm 17^{b}$ & -36.19 & $266 \pm 4^{a}$ & 2.70 & $174 \pm 1^{a}$ & 16.00 & $93 \pm 4^{\mathrm{a}}$ & -7.92 \\
\hline HJ4 & $1436 \pm 22^{b}$ & -27.36 & $968 \pm 27^{b}$ & -39.08 & $272 \pm 4^{a}$ & 5.02 & $177 \pm 4^{a}$ & 18.00 & $90 \pm 4^{\mathrm{a}}$ & -10.89 \\
\hline
\end{tabular}

The data are presented as the mean \pm standard deviation $(n=3)$. Different letters within the same column indicate significant differences $(P$ $<0.05)$ according to Duncan's multiple range test. $V R_{m} \%$ represents the degradation efficiency of heavy oil and four fractions. The same applies in the Tables below, unless otherwise specified. 
Table 2 Relative variations in chromatographic peak area of individual gasifiable $n$-alkanes in heavy oil after degradation by Aspergillus spp. strains HJ2 and HJ4 and enzyme preparations E2 and E4 


\begin{tabular}{|c|c|c|c|c|c|c|c|c|c|c|c|}
\hline \multirow{2}{*}{$\begin{array}{l}\text { Retention } \\
\text { time } \\
\text { (min) }\end{array}$} & \multirow{2}{*}{$\begin{array}{l}\text { Ctrl } \\
\text { Peak } \\
\text { area }\end{array}$} & \multicolumn{2}{|l|}{ HJ2 } & \multicolumn{2}{|l|}{ HJ4 } & \multirow{2}{*}{$\begin{array}{l}\text { Retention } \\
\text { time } \\
\text { (min) }\end{array}$} & \multirow{2}{*}{$\begin{array}{l}\text { Ctrl } \\
\text { Peak } \\
\text { area }\end{array}$} & \multicolumn{2}{|l|}{ E2 } & \multicolumn{2}{|l|}{ E4 } \\
\hline & & $\begin{array}{l}\text { Peak } \\
\text { area }\end{array}$ & $V R_{a} \%$ & $\begin{array}{l}\text { Peak } \\
\text { area }\end{array}$ & $V R_{a} \%$ & & & $\begin{array}{l}\text { Peak } \\
\text { area }\end{array}$ & $V R_{a} \%$ & $\begin{array}{l}\text { Peak } \\
\text { area }\end{array}$ & $V R_{a} \%$ \\
\hline 33.705 & 273782.2 & 87830.9 & $\overline{67.9}$ & 132902.9 & $\overline{51.5}$ & 21.953 & 0 & 53582.2 & - & 43534.5 & - \\
\hline 34.505 & 121444.3 & 103415.8 & $\overline{14.9}$ & 77981.9 & $\overline{35.8}$ & 23.804 & 42393.1 & 64895.8 & 53.1 & 50868.6 & 20.0 \\
\hline 34.725 & 66673.4 & 57271.0 & $\overline{14.1}$ & 0 & $\overline{100.0}$ & 25.651 & 53999.7 & 73266.6 & 35.7 & 62185.2 & 15.2 \\
\hline 35.15 & 242523.5 & 128486.8 & $-\overline{47.0}$ & 87237.1 & $\overline{6}-\overline{64.0}$ & 27.359 & 60772.0 & 83923.2 & 38.1 & 72783.1 & 19.8 \\
\hline 35.666 & 102722.8 & 186629.8 & 81.7 & 137882.6 & 34.2 & 29.035 & 69266.3 & 93490.0 & 35.0 & 85099.5 & 22.9 \\
\hline 35.932 & 119966.9 & 90799.5 & $\overline{24.3}$ & 60473.8 & $-\overline{49.6}$ & 30.645 & 84026.5 & 131741.2 & 56.8 & 115991.3 & 38.0 \\
\hline 36.143 & 88483.7 & 67070.4 & $\overline{24.2}$ & 57834.8 & $\overline{34.6}$ & 32.209 & 98793.5 & 185020.4 & 87.3 & 175945.0 & 78.1 \\
\hline 36.659 & 247365.5 & 142455.3 & $\overline{42.4}$ & 106912.7 & $\overline{56.8}$ & 33.692 & 132998.9 & 372787.8 & 180.3 & 383790.2 & 188.6 \\
\hline 37.013 & 123071.4 & 63092.1 & $-\overline{48.7}$ & 42298.9 & $\begin{array}{l}- \\
65.6\end{array}$ & 34.472 & 56953.7 & 144010.8 & 152.9 & 184841.5 & 224.6 \\
\hline 37.544 & 77791.0 & 50395.3 & $-\overline{35.2}$ & 0 & $\overline{100.0}$ & 34.736 & 42429.7 & 80588.0 & 89.9 & 99382.7 & 134.2 \\
\hline 38.099 & 284365.4 & 173945.7 & $\overline{38.8}$ & 0 & $\overline{100.0}$ & 35.139 & 168243.4 & 245320.7 & 45.8 & 282016.5 & 67.6 \\
\hline 38.16 & 0 & 55890.1 & - & 133879.2 & - & 35.465 & 70479.6 & 210165.8 & 198.2 & 323388.2 & 358.8 \\
\hline 38.422 & 187753.3 & 120771.3 & $\overline{35.7}$ & 0 & $\overline{100.0}$ & 36.137 & 48979.0 & 92257.7 & 88.4 & 312197.2 & 537.4 \\
\hline 38.847 & 128370.4 & 54638.4 & $\overline{57.4}$ & 0 & $\overline{100.0}$ & 36.648 & 183498.5 & 253092.2 & 37.9 & 286903.5 & 56.4 \\
\hline 39.502 & 107157.9 & 92600.1 & $\overline{13.6}$ & 0 & $\overline{100.0}$ & 36.919 & 41772.1 & 54143.1 & 29.6 & 70375.4 & 68.5 \\
\hline 40.553 & 165227.1 & 92845.0 & $\overline{47.0}$ & 0 & $\overline{100.0}$ & 37.003 & 54394.7 & 130283.5 & 139.5 & 172205.9 & 216.6 \\
\hline 41.007 & 82206.9 & 0 & $\overline{100.0}$ & 0 & $\overline{100.0}$ & 37.529 & 57113.2 & 91951.0 & 61.0 & 87954.1 & 54.0 \\
\hline 43.166 & 51843.7 & 0 & $\overline{100.0}$ & 0 & $\overline{100.0}$ & 37.816 & 41167.0 & 61650.3 & 49.8 & 136030.3 & 230.4 \\
\hline 30.67 & 65449.4 & 0 & $\overline{100.0}$ & 0 & $\overline{100.0}$ & 38.42 & 159099.6 & 177326.7 & 11.5 & 199632.6 & 25.5 \\
\hline 32.213 & 92606.9 & 0 & $\overline{100.0}$ & 0 & $\overline{100.0}$ & 38.814 & 60825.7 & 123250.6 & 102.6 & 168363.6 & 176.8 \\
\hline 33.027 & 56095.1 & 0 & $\overline{100.0}$ & 0 & $\overline{100.0}$ & 39.487 & 80050.9 & 122579.2 & 53.1 & 143343.8 & 79.1 \\
\hline 34.069 & 55144.5 & 0 & $\overline{100.0}$ & 0 & $\overline{100.0}$ & 39.812 & 42308.5 & 53926.7 & 27.5 & 62644.3 & 48.1 \\
\hline 35.548 & 128622.2 & 0 & $\overline{100.0}$ & 0 & $\overline{100.0}$ & 40.539 & 146760.8 & 186414.5 & 27.0 & 187064.7 & 27.5 \\
\hline 37.331 & 60972.8 & 0 & $\overline{100.0}$ & 0 & $\overline{100.0}$ & 43.133 & 71462.8 & 60389.7 & $\overline{15.5}$ & 54728.5 & $\overline{23.4}$ \\
\hline 39.201 & 54394.2 & 0 & $\overline{100.0}$ & 0 & $\overline{100.0}$ & 31.498 & 0 & 58638.5 & - & 55256.5 & - \\
\hline
\end{tabular}




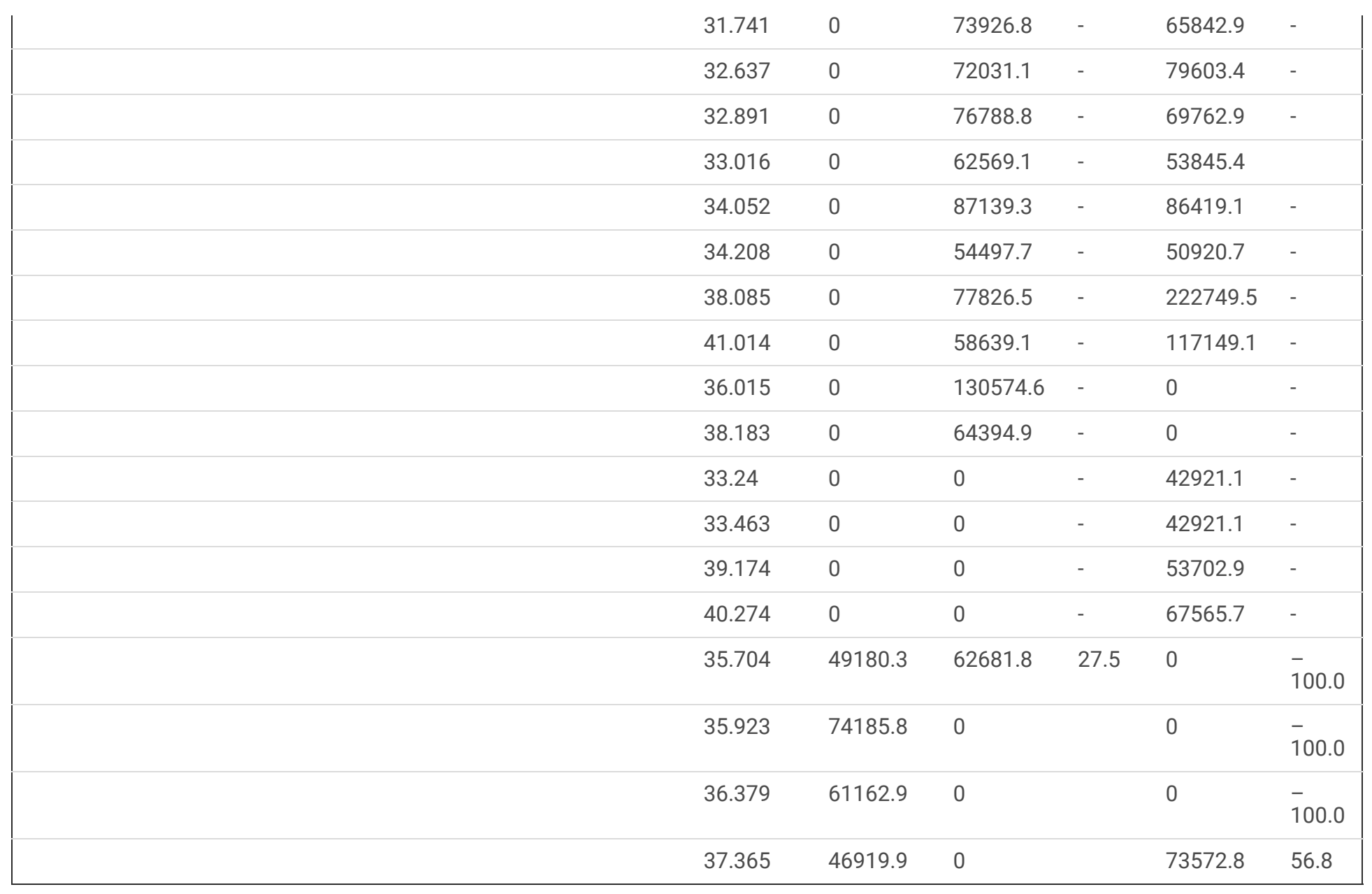

Table 3 The four fractions of heavy oil and gas production after treatment with fungal enzyme preparations at different concentrations

\begin{tabular}{|c|c|c|c|c|c|c|c|c|c|c|}
\hline \multirow[t]{2}{*}{$\begin{array}{l}\text { Enzyme } \\
\text { concentration }\end{array}$} & \multicolumn{2}{|c|}{$\begin{array}{l}\text { Alkanes } \\
\left(\mathrm{mg} 2 \mathrm{~g}^{-1}\right)\end{array}$} & \multicolumn{2}{|c|}{ 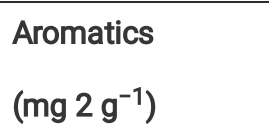 } & \multicolumn{2}{|c|}{ 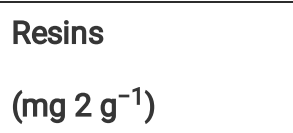 } & \multicolumn{2}{|c|}{$\begin{array}{l}\text { Asphaltenes } \\
\left(\mathrm{mg} 2 \mathrm{~g}^{-1}\right)\end{array}$} & \multicolumn{2}{|c|}{$\begin{array}{l}\text { Gas production } \\
\left.\text { (mL bottle }^{-1}\right)\end{array}$} \\
\hline & E2 & E4 & E2 & E4 & E2 & E4 & E2 & E4 & E2 & E4 \\
\hline $0 \%$ & $\begin{array}{l}1579 \pm \\
4^{\mathrm{a}}\end{array}$ & $\begin{array}{l}1579 \pm \\
4^{\mathrm{a}}\end{array}$ & $282 \pm 4^{d}$ & $\begin{array}{l}282 \pm \\
4^{e}\end{array}$ & $\begin{array}{l}163 \pm \\
10^{d}\end{array}$ & $\begin{array}{l}163 \pm \\
10^{c}\end{array}$ & $\begin{array}{l}101 \pm \\
3^{a}\end{array}$ & $\begin{array}{l}101 \pm \\
3^{a}\end{array}$ & $0.0 \pm 0.0^{\mathrm{g}}$ & $0.0 \pm 0.0^{g}$ \\
\hline $2 \%$ & $\begin{array}{l}1322 \pm \\
31^{b}\end{array}$ & $\begin{array}{l}1291 \pm \\
11^{\mathrm{b}}\end{array}$ & $369 \pm 7^{c}$ & $\begin{array}{l}372 \pm \\
8^{d}\end{array}$ & $\begin{array}{l}167 \pm \\
3^{d}\end{array}$ & $\begin{array}{l}178 \pm \\
21^{b c}\end{array}$ & $\begin{array}{l}98 \pm \\
2^{\mathrm{ab}}\end{array}$ & $\begin{array}{l}98 \pm \\
3^{\mathrm{ab}}\end{array}$ & $\begin{array}{l}25.5 \pm \\
2.1^{f}\end{array}$ & $\begin{array}{l}47.0 \pm \\
1.4^{f}\end{array}$ \\
\hline $4 \%$ & $\begin{array}{l}1289 \pm \\
13^{\mathrm{bc}}\end{array}$ & $\begin{array}{l}1277 \pm \\
21^{\mathrm{bc}}\end{array}$ & $411 \pm 3^{b}$ & $\begin{array}{l}419 \pm \\
4^{c}\end{array}$ & $\begin{array}{l}188 \pm \\
1^{b c}\end{array}$ & $190 \pm 5^{b}$ & $\begin{array}{l}95 \pm \\
3^{\mathrm{abc}}\end{array}$ & $\begin{array}{l}94 \pm \\
4^{\text {bc }}\end{array}$ & $\begin{array}{l}65.5 \pm \\
2.1^{\mathrm{e}}\end{array}$ & $\begin{array}{l}89.5 \pm \\
2.1^{\mathrm{e}}\end{array}$ \\
\hline $5 \%$ & $\begin{array}{l}1250 \pm \\
2^{\text {cd }}\end{array}$ & $\begin{array}{l}1252 \pm \\
9^{c}\end{array}$ & $\begin{array}{l}416 \pm \\
3^{\mathrm{ab}}\end{array}$ & $\begin{array}{l}465 \pm \\
1^{\mathrm{a}}\end{array}$ & $\begin{array}{l}214 \pm \\
15^{\mathrm{a}}\end{array}$ & $229 \pm 4^{a}$ & $\begin{array}{l}93 \pm \\
7^{\mathrm{abc}}\end{array}$ & $\begin{array}{l}93 \pm \\
1^{b c}\end{array}$ & $\begin{array}{l}79.0 \pm \\
1.4^{\mathrm{d}}\end{array}$ & $\begin{array}{l}101.0 \pm \\
2.8^{\mathrm{d}}\end{array}$ \\
\hline $6 \%$ & $\begin{array}{l}1228 \pm \\
27^{d}\end{array}$ & $\begin{array}{l}1183 \pm \\
16^{d}\end{array}$ & $\begin{array}{l}425 \pm \\
11^{\mathrm{ab}}\end{array}$ & $\begin{array}{l}445 \pm \\
5^{b}\end{array}$ & $\begin{array}{l}202 \pm \\
1^{\text {ab }}\end{array}$ & $197 \pm 3^{b}$ & $\begin{array}{l}91 \pm \\
2^{\mathrm{bc}}\end{array}$ & $\begin{array}{l}92 \pm \\
1^{b c}\end{array}$ & $\begin{array}{l}86.0 \pm \\
1.4^{\mathrm{c}}\end{array}$ & $\begin{array}{l}118.5 \pm \\
3.5^{c}\end{array}$ \\
\hline $8 \%$ & $\begin{array}{l}1195 \pm \\
12^{\text {de }}\end{array}$ & $\begin{array}{l}1175 \pm \\
16^{d}\end{array}$ & $\begin{array}{l}417 \pm \\
8^{\text {ab }}\end{array}$ & $\begin{array}{l}435 \pm \\
4^{b}\end{array}$ & $\begin{array}{l}174 \pm \\
2^{\text {cd }}\end{array}$ & $190 \pm 4^{b}$ & $87 \pm 1^{c}$ & $\begin{array}{l}90 \pm \\
3^{c}\end{array}$ & $\begin{array}{l}91.0 \pm \\
1.4^{\mathrm{b}}\end{array}$ & $\begin{array}{l}163.0 \pm \\
4.2^{\mathrm{b}}\end{array}$ \\
\hline $10 \%$ & $\begin{array}{l}1155 \pm \\
52^{\mathrm{e}}\end{array}$ & $\begin{array}{l}1143 \pm \\
5^{\mathrm{a}}\end{array}$ & $427 \pm 3^{a}$ & $\begin{array}{l}423 \pm \\
1^{c}\end{array}$ & $\begin{array}{l}158 \pm \\
11^{d}\end{array}$ & $188 \pm 4^{b}$ & $88 \pm 3^{c}$ & $\begin{array}{l}89 \pm \\
1^{c}\end{array}$ & $\begin{array}{l}100.0 \pm \\
2.8^{\mathrm{a}}\end{array}$ & $\begin{array}{l}186.5 \pm \\
2.1^{\mathrm{a}}\end{array}$ \\
\hline
\end{tabular}


Table 4 Effect of addition of enzyme preparations and surfactants on the four fractions of heavy oil

\begin{tabular}{|c|c|c|c|c|c|}
\hline Sample & $\begin{array}{l}\text { Alkanes } \\
\left(\mathrm{mg} 2 \mathrm{~g}^{-1}\right)\end{array}$ & $\begin{array}{l}\text { Aromatics } \\
\left(\mathrm{mg} 2 \mathrm{~g}^{-1}\right)\end{array}$ & $\begin{array}{l}\text { Resins } \\
\left(\mathrm{mg} 2 \mathrm{~g}^{-1}\right)\end{array}$ & $\begin{array}{l}\text { Asphaltenes } \\
\left(\mathrm{mg} 2 \mathrm{~g}^{-1}\right)\end{array}$ & $\begin{array}{l}\text { Gas production } \\
\left(\mathrm{mL} \text { bottle } \mathrm{e}^{-1}\right)\end{array}$ \\
\hline Ctrl & $1567 \pm 17^{a}$ & $274 \pm 2^{d}$ & $157 \pm 3^{b c}$ & $101 \pm 1^{a}$ & $0.0 \pm 0.0^{f}$ \\
\hline E2 & $1313 \pm 19^{\text {cde }}$ & $417 \pm 13^{a}$ & $181 \pm 8^{a b}$ & $95 \pm 4^{a}$ & $67.0 \pm 1.4^{c}$ \\
\hline EB2 & $1353 \pm 3^{b c}$ & $352 \pm 2^{b}$ & $147 \pm 7^{c d}$ & $97 \pm 1^{a}$ & $56.5 \pm 2.1^{d}$ \\
\hline EC2 & $1321 \pm 6^{c d}$ & $330 \pm 13^{c}$ & $104 \pm 11^{e}$ & $96 \pm 3^{a}$ & $50.0 \pm 2.8^{e}$ \\
\hline E4 & $1289 \pm 7^{\text {de }}$ & $428 \pm 11^{a}$ & $202 \pm 21^{a}$ & $93 \pm 4^{a}$ & $86.5 \pm 2.1^{a}$ \\
\hline EB4 & $1371 \pm 40^{b}$ & $372 \pm 5^{b}$ & $173 \pm 9^{b}$ & $97 \pm 3^{a}$ & $75.5 \pm 2.1^{b}$ \\
\hline EC4 & $1272 \pm 9 e$ & $371 \pm 4^{b}$ & $132 \pm 2^{d}$ & $96 \pm 4^{a}$ & $52.0 \pm 4.2^{\mathrm{de}}$ \\
\hline
\end{tabular}

E2 and E4 are crude enzyme solutions; EB2 and EB4 indicate the use of crude enzyme solutions + bacterial fermentation broth containing biosurfactant; EC2 and EC4 indicate the use of crude enzyme solutions + sodium dodecyl sulfate $\left(1 \mathrm{mg} \mathrm{mL}^{-1}\right)$.

Table 5 Heavy oil viscosity reduction and removal efficiencies of fungal enzyme preparations from Aspergillus spp.

\begin{tabular}{|lllll|}
\hline Sample & $\begin{array}{l}\text { Viscosity } \\
\text { (mPa.s) }\end{array}$ & Reduction efficiency (\%) & Removal efficiency (REs, \%) & $R_{\text {s }} / R_{\text {Ctrl }}$ \\
\hline Ctrl & $29,700 \pm 1500^{a}$ & - & $3.43 \pm 0.13^{b}$ & - \\
\hline E2 & $13,700 \pm 1200^{\mathrm{b}}$ & $53.87 \%$ & $7.85 \pm 0.16^{\mathrm{a}}$ & 2.29 \\
\hline E4 & $10,000 \pm 1000^{\mathrm{c}}$ & $66.33 \%$ & $8.48 \pm 0.13^{\mathrm{a}}$ & 2.47 \\
\hline
\end{tabular}

\section{Figures}




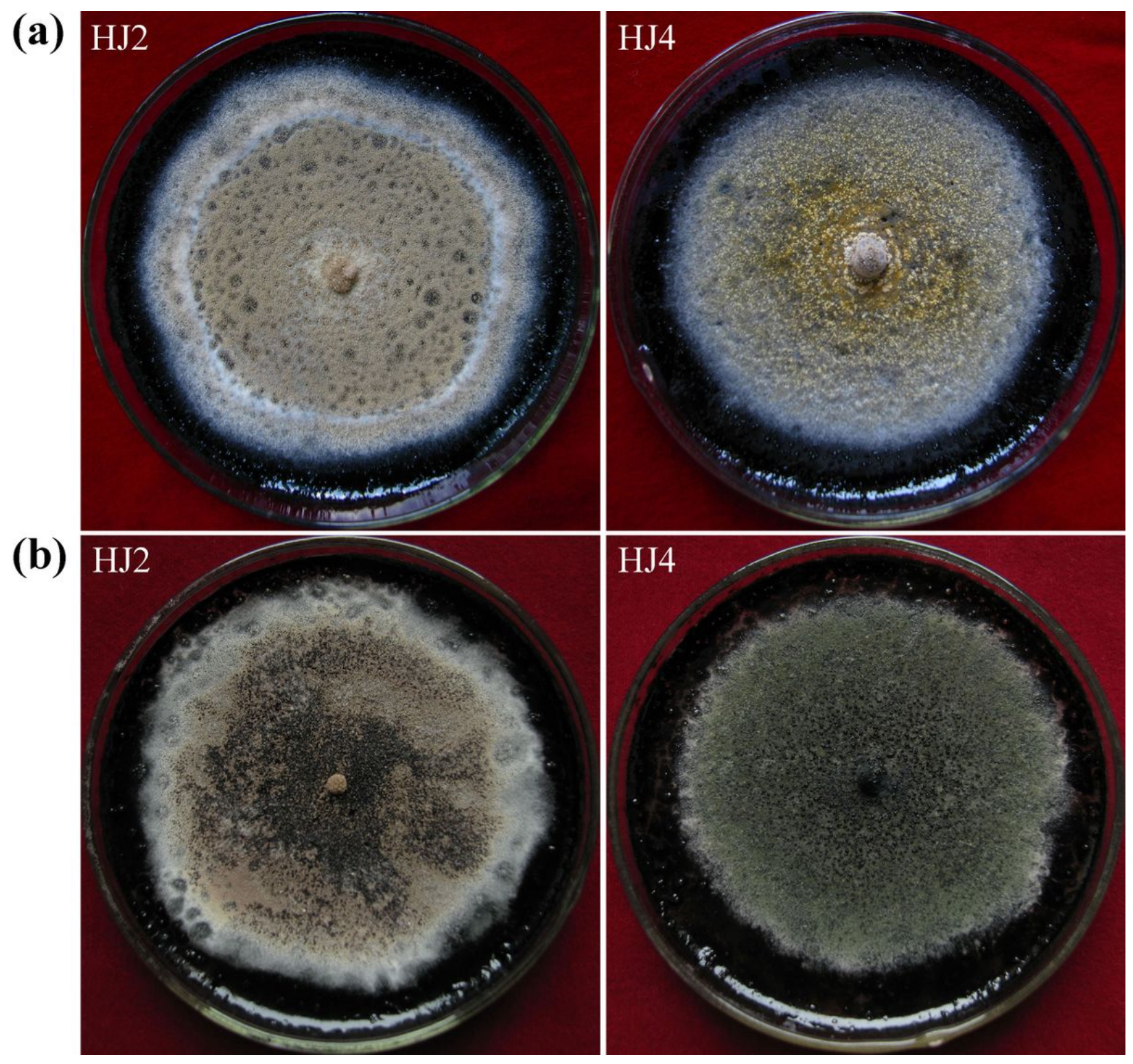

Figure 1

Photographs showing luxuriant growth of two fungal cultures on heavy oil (a) and bitumen (b) plates (9 cm in diameter) of mineral salts medium 

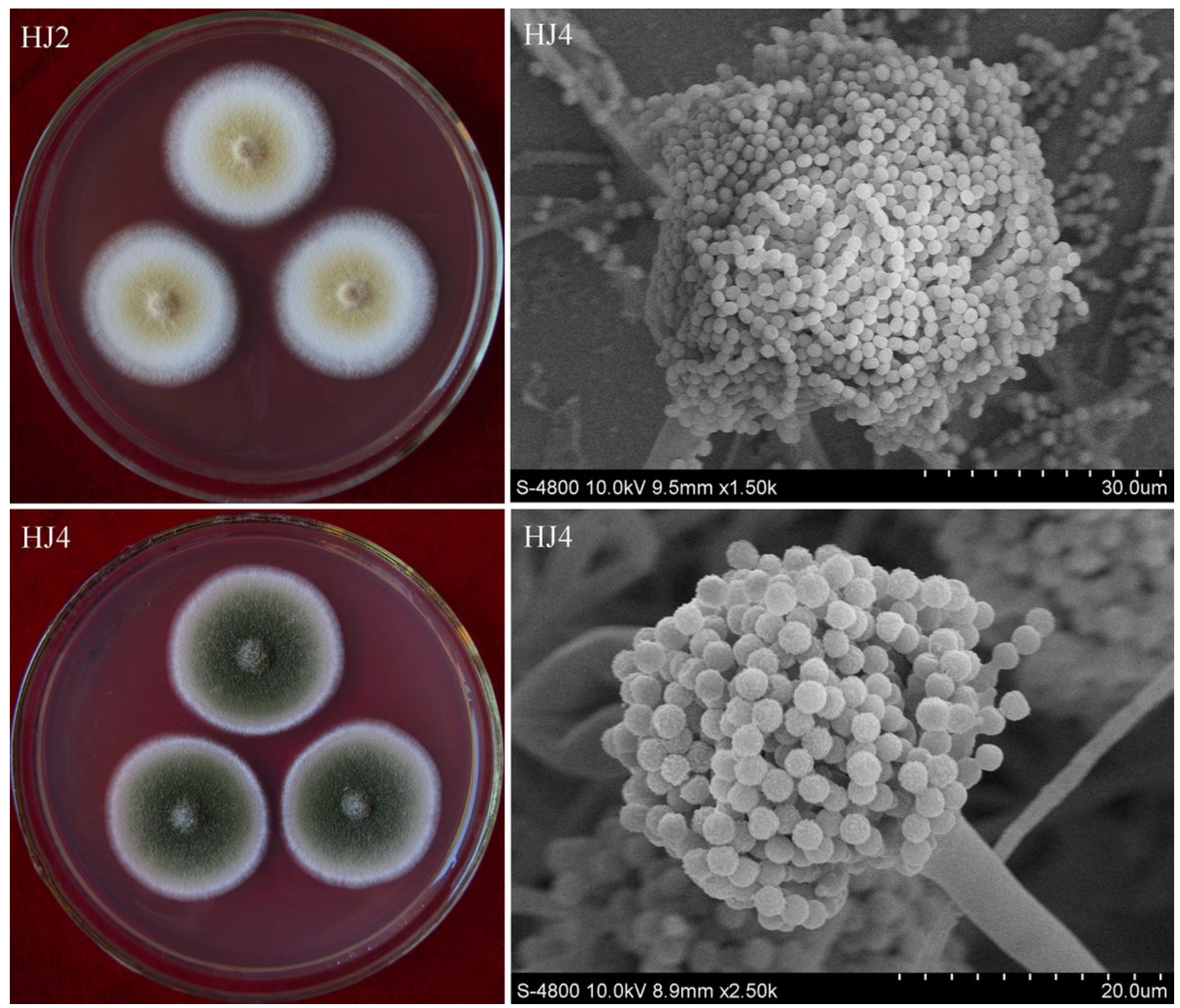

\section{Figure 2}

Distinctive colony morphologies and spore structures of two fungal cultures isolated in this study, Aspergillus terreus HJ2 and A. nidulans HJ4 


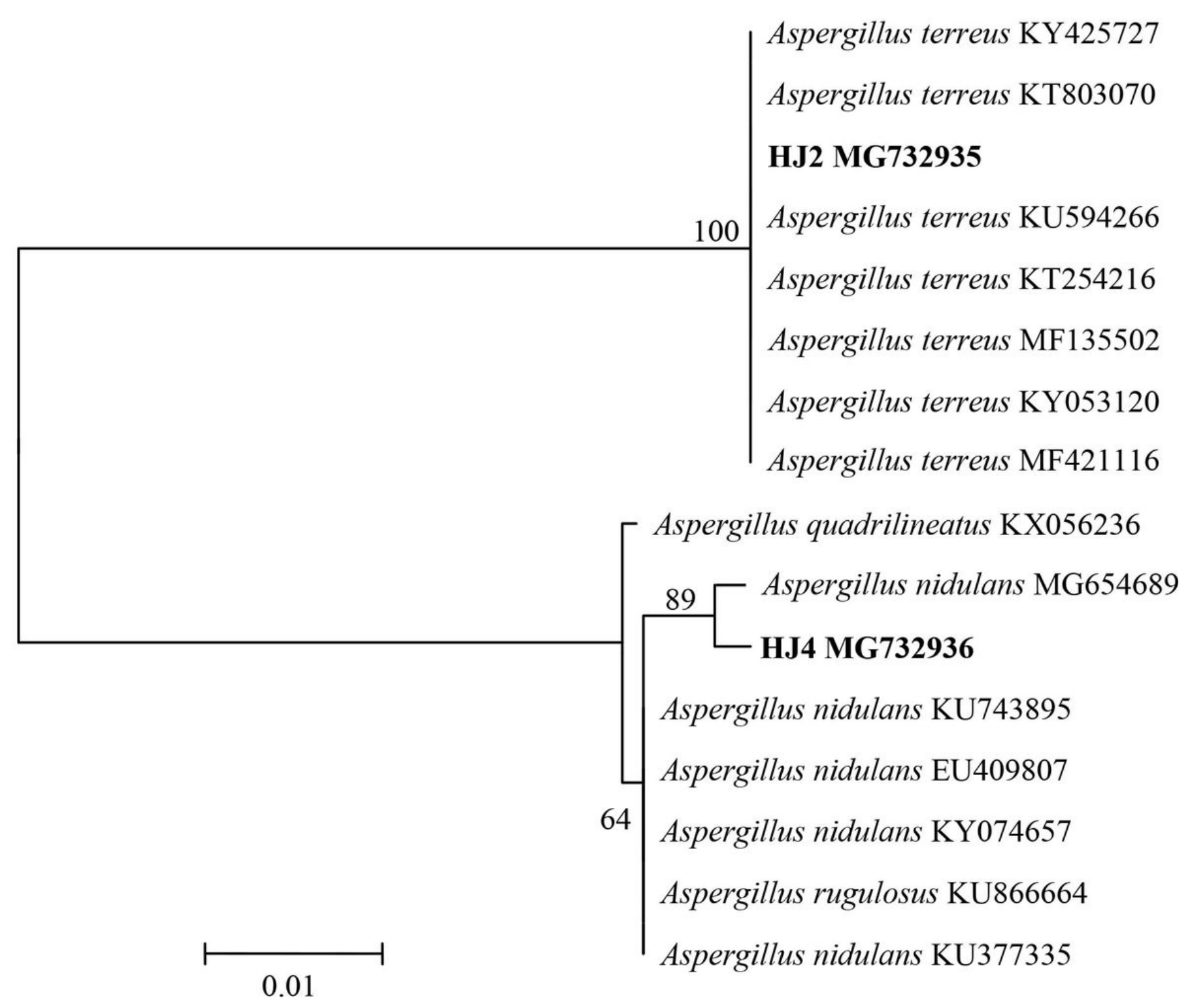

Figure 3

Phylogenetic tree constructed by the neighbor-joining method from rDNA-ITS sequences of two fungal cultures obtained in this study (HJ2 and HJ4) and their close relatives retrieved from the GenBank database. Bootstrap values are shown at nodes for frequencies $\geq 50 \%$ ( 1000 bootstrap resamplings). Bar indicates $1 \%$ sequence variance 


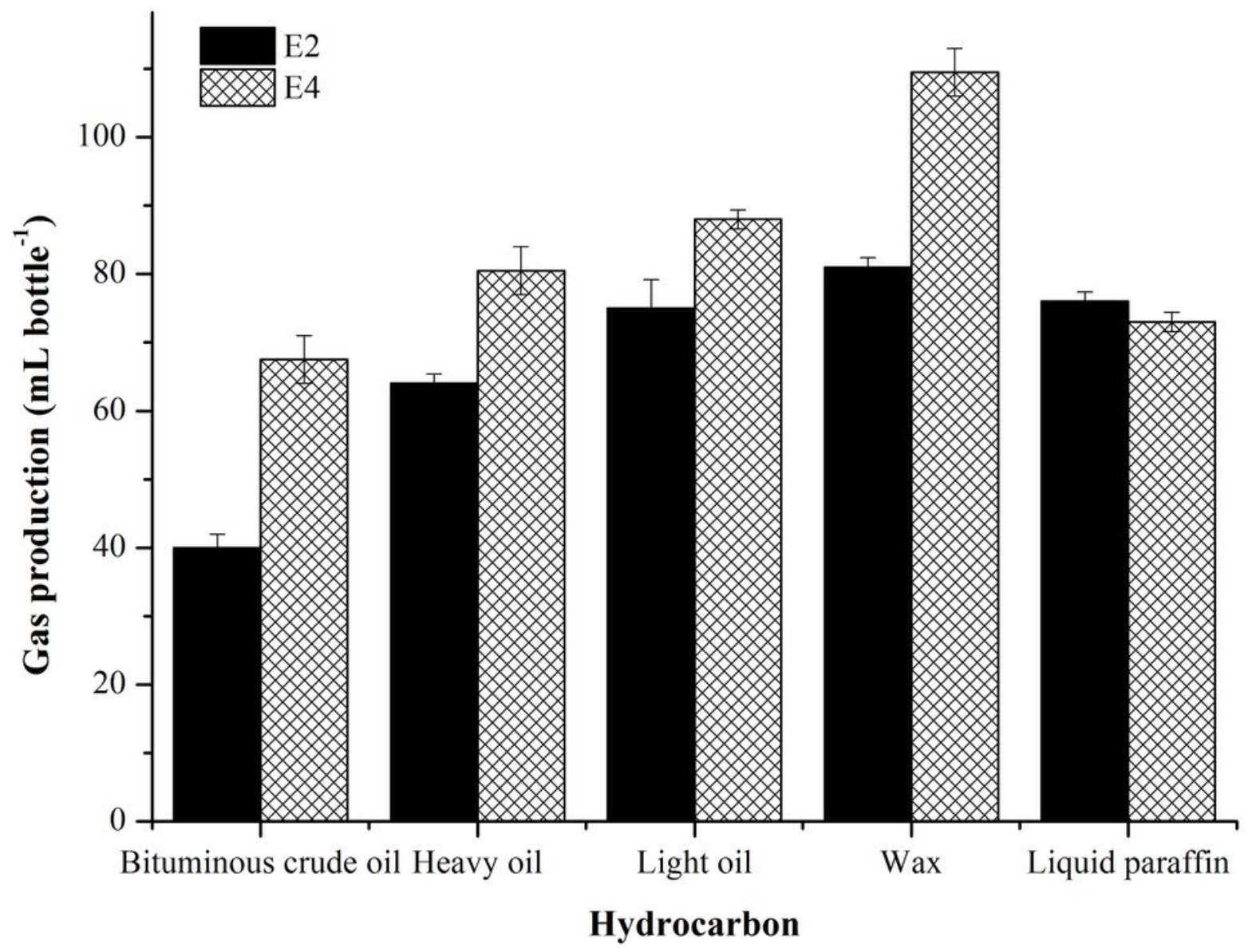

Figure 4

Gas production from hydrocarbon degradation by two fungal enzyme preparations after $15 \mathrm{~d}$ of incubation. The data are presented as the mean \pm standard deviation $(n=3)$ and error bars are standard deviations (means \pm SD)

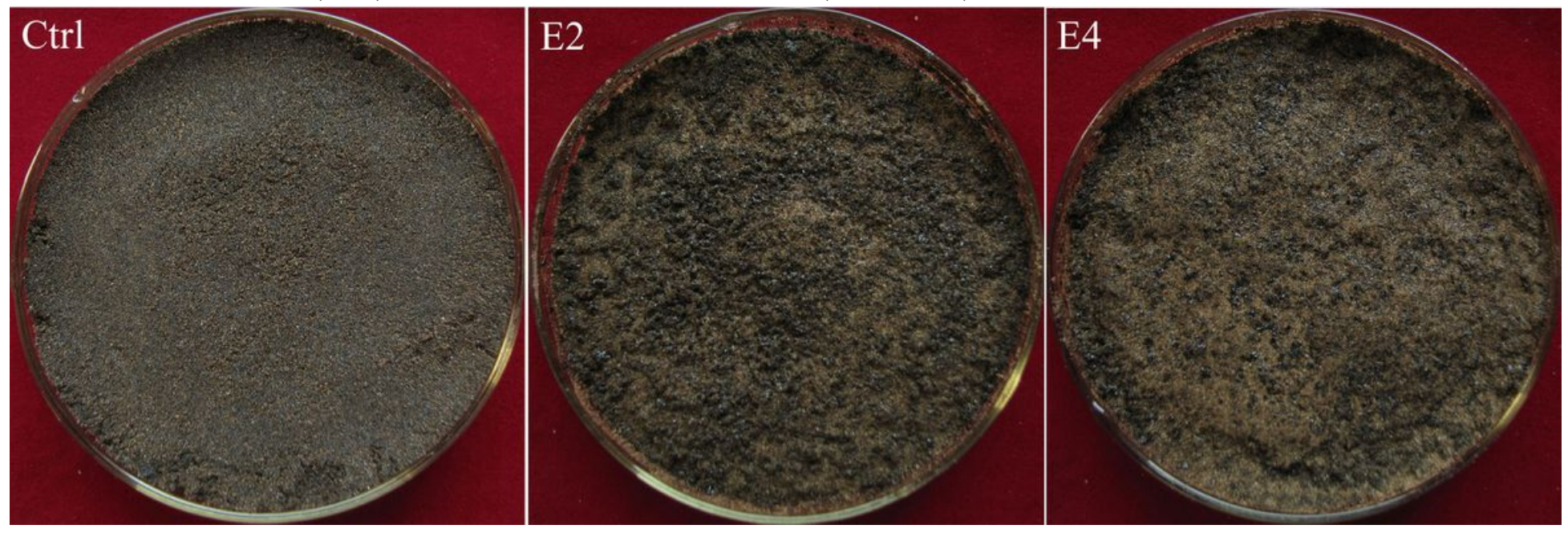

Figure 5

Photographs showing the removal efficiency of heavy oil adsorbed on artificially contaminated sand by crude enzyme solutions from E2 and $\mathrm{E} 4$ 


\section{Supplementary Files}

This is a list of supplementary files associated with this preprint. Click to download.

- GraphicalAbstract.tif 